\title{
Assessment of precision, concordance, specificity, and sensitivity of islet cell antibody measurement in 41 assays
}

\author{
E. Bonifacio ${ }^{1,2}$, C. Boitard ${ }^{3}$, H. Gleichmann ${ }^{4}$, M. A. Shattock ${ }^{1}$, J.L. Molenaar ${ }^{5}$, G.F. Bottazzo ${ }^{1}$ and co-authors* \\ 1 Department of Immunology, University College and Middlesex School of Medicine, London, UK \\ 2 Department of Clinical Immunology, QE11 Medical Centre, Nedlands, Western Australia \\ 3 Immunologie Clinique and INSERM U25, Hopital Necker, Paris, France \\ ${ }^{4}$ Clinical Department, Diabetes Research Institute, University of Düsseldorf, Düsseldorf, Federal Republic of Germany \\ ${ }^{5}$ Klinik Immunologie, Delft, The Netherlands
}

\begin{abstract}
Summary. Forty-one assays were analysed at the 3 rd International Workshop on the standardisation of islet cell antibodies. Analysis of precision demonstrated assays consistently detecting blind duplicates within one doubling dilution and capable of discriminating one doubling dilution differences in islet cell antibody concentration. Some assays, however, reported duplicates discrepantly by more than seven doubling dilutions, and consequently could not distinguish even large quantities of islet cell antibodies. Precision was best in assays from laboratories which had participated in all three Standardisation Workshops and was not dependent upon methodology. The use of the Juvenile, Diabetes Foundation reference islet cell antibody standard and standard curves reduced the scatter of results, and was best amongst assays with better precision. Twenty-seven assays reported
\end{abstract}

all ten blood donor sera as negative. However, 14 assays did not, and specificity (negativity in health) was $<50 \%$ in three assays. Low specificity was strongly associated with poor precision. The detection limit of assays ranged from $<5$ to 50 JDF units and was partially dependent upon methodology. Assays incorporating extended incubation had the lowest detection limits without a decrease in the specificity of the ten blood donor sera. Precise quantification is fundamental for the standardisation and comparability of islet cell antibodies. Precise quantitative assays have been identified and reference standards and common units established.

Key words: Islet cell antibody, Type 1 (insulin-dependent) diabetes, standards, quality control, Juvenile Diabetes Foundation units.
Islet cell antibody (ICA) determinations have been used as a serological marker for the identification of individuals at risk of developing Type 1 (insulin-dependent) diabetes mellitus [1-3]; the diagnosis of Type 1 diabetes in cases of secondary failure, or unusual presentation [4-6]; and

\footnotetext{
* S. Assa, Perah-Tiqua, Israel; A. Arnaiz-Villena, Madrid, Spain; J. Barbosa, Minneapolis, Minnesota, USA; C. Betterle, Padua, Italy, E. Beutner, Buffalo, New York, USA; G.Bright, Charleston, South Carolina, USA; H.Chapel, Oxford, U.K.; M.Codina, Barcelona, Spain; R.Dawkins, Perth, Western Australia; E.Deitsch, Vienna, Austria; U.Di Mario, Rome, Italy; G. Eisenbarth, Boston, Massachusetts, USA; R. Elliot, Auckland, New Zealand; R. Gomis de Barbara, Barcelona, Spain; T. Hanafusa, Osaka, Japan; L. Harrison, Victoria, Australia; K.Helmke, Giessen, FRG; C.Howard, Oregon, USA; P.In’t Veld, Brussels, Belgium; D. Kawathara, Orange, California, USA; T. Kobayashi, Tokyo, Japan; M. Landin, Malmö, Sweden; A..Lernmark, Gentoft, Denmark; N. Maclaren, Gainesville, Florida, USA; T. Mandrup-Poulsen, Gentofte, Denmark; R. Manna, Rome, Italy; A. Miettinen, Finland; J. Palmer, Seattle, Washington, USA; P.Panczel, Budapest, Hungary, J. Peter, Los Angeles, California, USA; K. Pirich, Vienna, Austria; L. Quenette, La Jolla, California, USA; G.Reeves, Nottingham, UK; K. Reinauer, Tübingen, FRG; W.Scherbaum, Ulm FRG; L.Scott-Morgan, Southampton, UK; D. Vergani, London, U.K.; B. Vialettes, Marseille, France
}

monitoring patients on insulin therapy [7, 8], or undergoing therapeutic trials with cyclosporine $[9,10]$. Since ICA were first described [11], numerous methodological modifications to the standard indirect immunofluorescent (IFL) assay have been proposed [12-18]. An assessment of inter-assay comparability was essential for the validity of ICA in diabetes research, and accordingly, four International Workshops have been held. The first showed a large scatter of results between laboratories, and suggested that the availability of reference sera would allow laboratories to express ICA in arbitrary, but common units [19]. A reference standard - Juvenile Diabetes Foundation (JDF) standard - was proposed and tested in the stage II Workshop. The use of standard curves constructed from this standard improved precision and concordance between laboratories $[20,21]$.

The stage III workshop was designed so as to (1) assess the precision, and (2) begin studies on the specificity (negativity in health), and sensitivity (positivity in disease) of the ICA assays. These parameters in 41 assays are analysed here, and their importance in the development of an international standardisation programme of ICA measurement discussed. 
Table 1. Characteristics and performance of 41 assays in the Stage III ICA Standardisation Workshop (see Materials and methods)

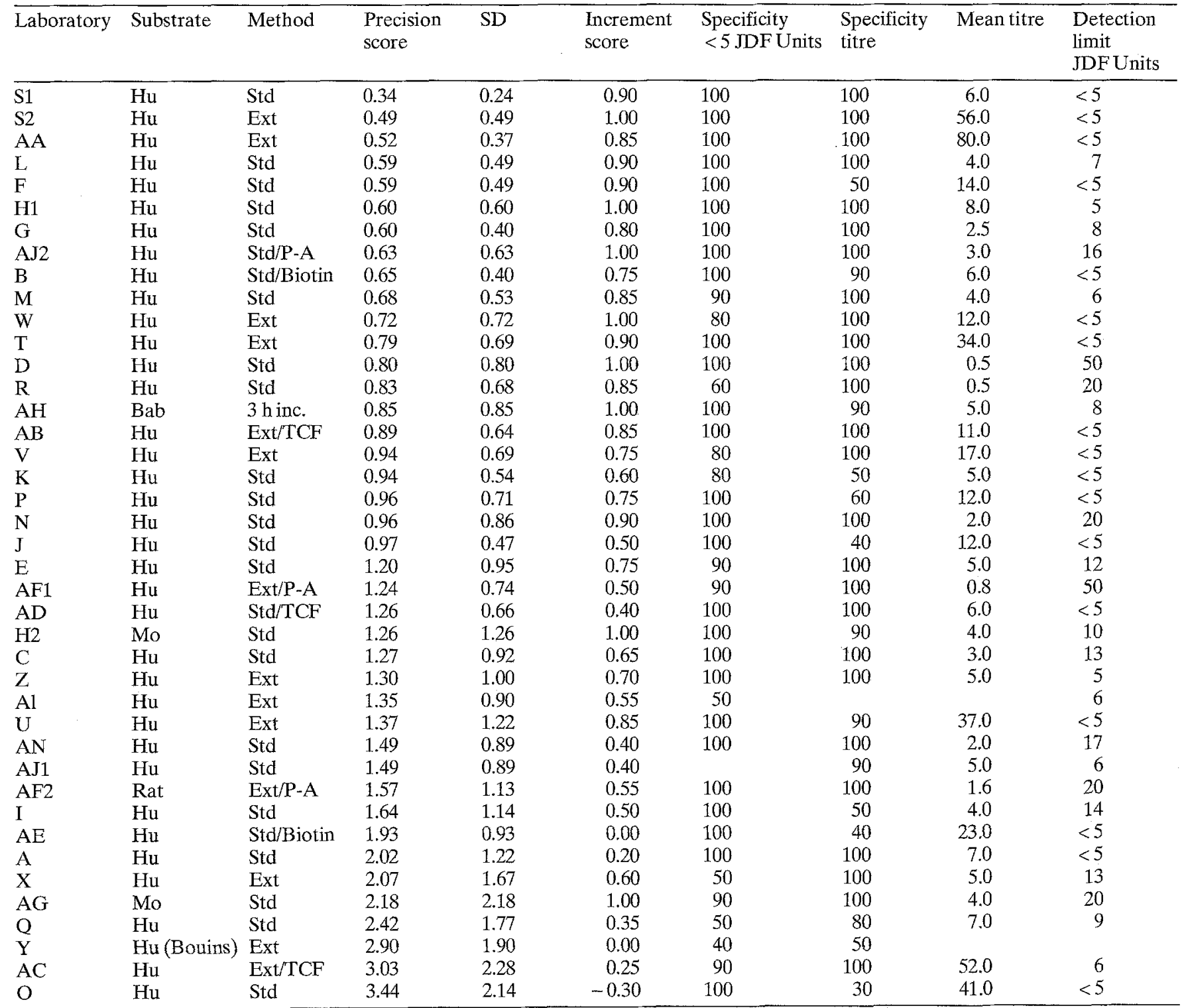

$\mathrm{Hu}=$ human; $\mathrm{Bab}=$ baboon; $\mathrm{Mo}=$ monkey; $\mathrm{P}-\mathrm{A}=$ FITC protein $\mathrm{A} ; \mathrm{TCF}=$ Two colour immunoflourescent

\section{Materials and methods}

\section{Serum exchange sera}

Forty-three coded $0.5 \mathrm{ml}$ freeze-dried serum samples were prepared by H.Richter-Oleson, Copenhagen, Denmark, and distributed to participants along with a disclosed $2 \mathrm{ml}$ freeze-dried aliquot of the JDF standard [20]. The set of coded samples included blood donor sera and 15 standard ICA sera in duplicate as previously described [22].

\section{Serum exchange participants}

The coded sera were sent to 50 laboratories. Results are available from 45 assays performed in 41 of the laboratories. Four laboratories did not detect ICA in any of the samples, and these were not included in the remainder of the analysis.

\section{ICA assays}

Of the 41 assays analysed, 26 used the conventional IFL assay (Std) with $<1$ h serum incubation [19], 14 incorporated extended $(>12 \mathrm{~h})$ incubation of sera (Ext) as previously described [12], and one assay used a serum incubation time of $3 \mathrm{~h}$. In addition, three assays used the modification of the two colour immunofluorescent (TCF) method [13], three the FITC-protein A (P-A) method [14] and two the biotin-avidin labelling (Biotin) method [15]. Thirty-seven assays used human tissue as substrate, one of which was Bouin's fixed, two monkey, one baboon, and one rat tissue (Table 1).

All but one assay $(\mathrm{Al})$ reported ICA results as end point titres.

\section{Precision}

Standard deviation. This was calculated from duplicates. For each assay, the difference of each duplicate titre from the geometric mean of the corresponding duplicate pairs in that laboratory was calculated. The standard deviation (SD) of the difference of duplicates from their mean was determined and became one measure of preci- 
a

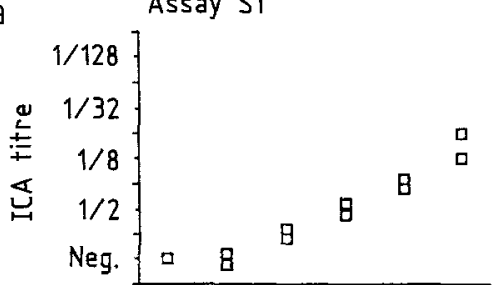

b

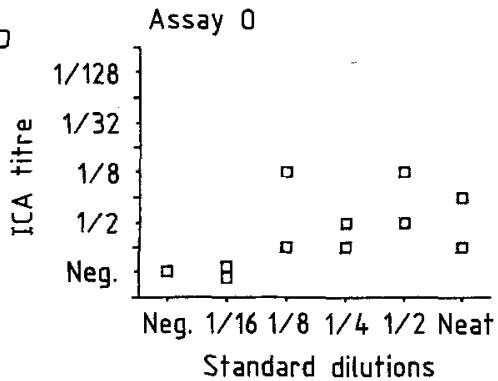

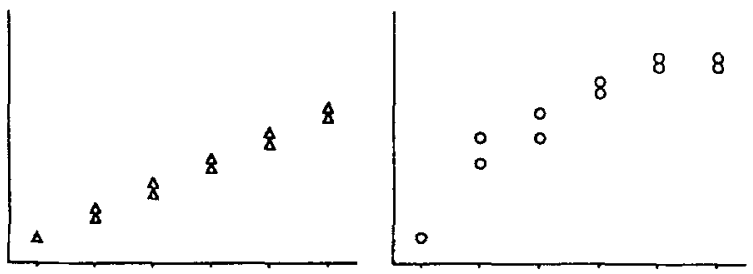

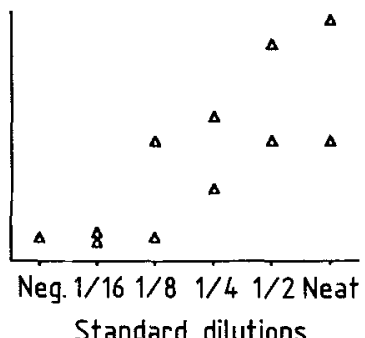

sion. The smaller the SD the less overall scatter of duplicates. Duplicates which were reported as negative on each occasion were excluded, as were those where one or both of the duplicates were reported as greater than a titre. Where ICA was detected in only one duplicate, the negative result was considered as one doubling dilution below the lowest reported titre in that assay. The number of separate duplicates used to calculate the SD in individual assays ranged from 12 (6 pairs) to 30 ( 15 pairs).

Increment score. A scoring system was used to determine the ability of assays to discriminate dilution intervals of each of the standard sera.

- 1 point was given if the geometric mean of the duplicates was higher than the previous dilutions;

- no points were given when the geometric mean of the duplicates was the same as the previous dilution;

- 1 point was subtracted if the geometric mean of the duplicates was lower than previous standard dilutions.

The total score for each of the three standard dilution series was summed and divided by the number of standard serum dilutions assessed. The maximum possible score was 1 . The higher the increment score, the better the assay could discriminate between dilution increments (Fig. $1 \mathrm{a}$ and $\mathrm{b}$ ).

Precision score. This was calculated from the sum of the SD and ( 1 minus the increment score).

\section{Interpolation to JDF units}

Laboratories were asked to prepare dilutions of the disclosed JDF standard serum (80 JDF units) in negative serum and to quantify these in the same way and in parallel with the 43 coded samples. The standard curve for each laboratory was calculated using a linear or polynomial regression analysis, and the result in JDF units for each of the 43 coded samples was interpolated from the assay standard curve as in the Stage II Workshop [20].

\section{Detection limit}

The median interpolated value from all assays for each serum was determined and became the "consensus JDF units" for that serum. The limit of detection for individual assays was calculated by plotting for each of the standard serum dilutions in which ICA was detected,
Fig.1a, b. Dilution curves of standard sera I ( $\square$ ) and II (O), and the JDF standard $(\triangle)$ tested by two assays in the Workshop. Assay S1 (a) distinguished all four dilution increments in serum I and the JDF standard, and three of four increments in serum II dilutions (increment score $=0.9$ ). All duplicates were within 1 doubling dilution $(\mathrm{SD}=0.24)$. The resultant precision score $=0.34$ (see Materials and methods). In contrast, in assay $\bigcirc(\mathbf{b})$ duplicates were up to seven doubling dilutions different $(\mathrm{SD}=2.14)$, and although the JDF standard dilutions were ranked correctly, the assay could not discriminate intervals for sera I and II (increment score $=-0.3$ ). The resultant precision score for assay 0 was 3.44 the $\log _{2}$ observed titre on the ordinate vs the $\log _{2}$ consensus JDF unit on the abscissa. The linear regression equation was calculated, and the intercept on the abscissa was the detection limit for that assay.

\section{Specificity}

This was defined as the percentage of negative results in health, and was calculated from the proportion of the 10 random blood donor sera reported as negative (titres) or $<5 \mathrm{JDF}$ units (interpolated units).

\section{Statistical analysis}

Comparisons of groups were performed using the one tailed $\chi^{2}$ test with Yates correction, correlation coefficient $(r)$, and the Wilcoxon two tailed rank sum test.

\section{Results}

\section{Assay precision}

Precision profiles given by the SD, increment score, and precision score for each assay are summarised in Table 1. The SD of duplicate differences ranged from 0.34 to 2.28 (median 0.94); the increment score from 1 to -0.3 (median 0.75 ); and the precision score from 0.34 to 3.44 (median 0.97). The SD correlated with the increment score $(r=0.53 ; p<0.001)$, and assays which quantified duplicates reproducibly also distinguished small increments of ICA (Fig. 1 a), while those with large precision SD could not distinguish even large quantities of ICA (Fig. 1b).

Precision did not correlate with methodology. Precision scores ranged from $<0.5$ to $>3$ in assays using either the standard IFL technique or incorporating extended incubation times. Assays using protein-A, biotin-avidin conjugates and TCF methods were few, and their precision scores were not different from the other methods (Fig. 2a). The precision score was associated with the number of ICA workshops in which the laboratories had 

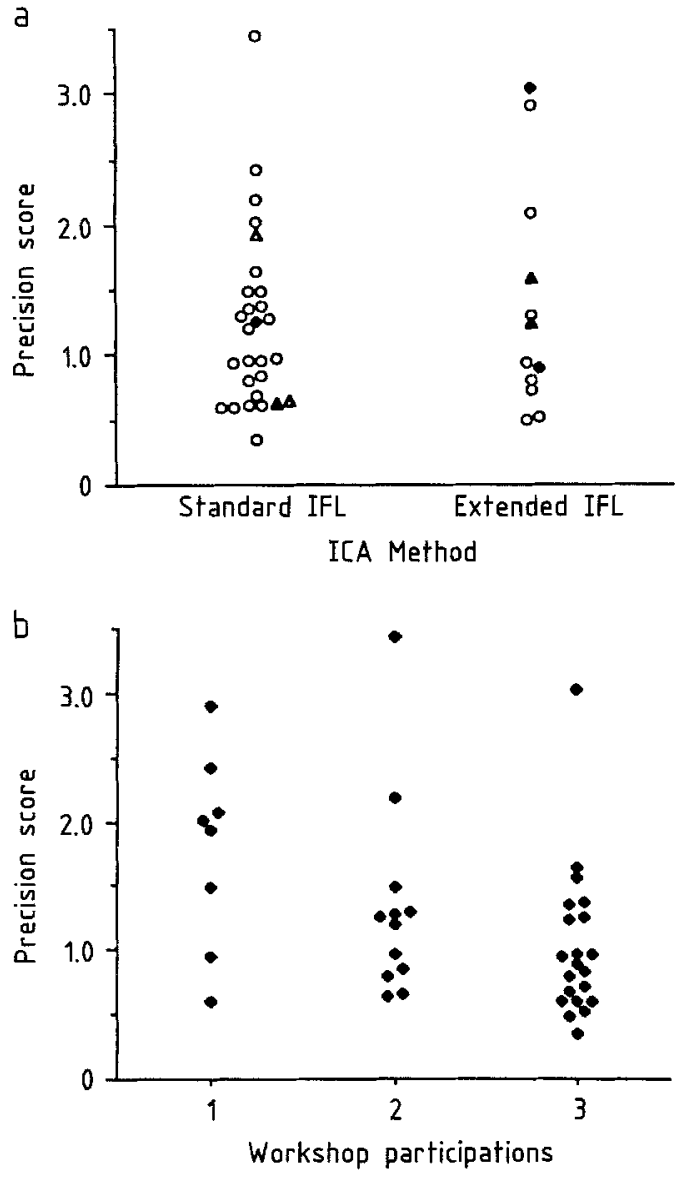

Fig. 2 a,b. Influence on precision by ICA method (a), and Workshop participation (b). No differences were seen between standard immunofluorescent (IFL) assays with or without extended incubation $(O)$, or other modifications: two-colour immunofluorescent $(\diamond)$; FITC-protein $A(\triangle)$; Biotin anti $\operatorname{IgG}(\triangle)$. Laboratories which had participated in all three Workshops had better precision scores than those participating for the first time $(p<0.02$, Wilcoxon rank sum test)

participated (Fig.2b). Assays from laboratories which had participated in all three IDW Workshops had lower precision scores than those from laboratories which had participated in only one Workshop $(p<0.02$; Wilcoxon rank sum test).

\section{Interpolation to JDF units}

The scatter of results improved after interpolation into JDF units, and was dependent upon assay precision (Figs. $3 \mathrm{a}$ and b). Only 34 (43\%) of 79 ICA titres reported for the blind JDF standard were within 1 doubling dilution of the median titre, whilst after interpolation from the standard curves, $57(72 \%)$ of the results in JDF units were within $1 \log _{2}$ JDF unit $\left(\chi^{2}=10.9 ; p<0.0005\right)$. Scatter was reduced regardless of the precision score, although it was significantly less amongst assays with small precision scores: 34 ( $81 \%$ ) of the interpolated JDF units from assays with precision scores $<1$ were within $1 \log _{2}$ JDF unit vs 23 $(62 \%)$ of results from assays with precision scores $>1$.
Other exchange sera gave similar results (data not shown).

\section{ICA specificity in blood donor sera}

The random blood donor sera and normal human serum diluent were reported as negative in most assays, with the concordance between $82 \%$ and $92.5 \%$. Titres up to $1 / 64$, however, were reported for these sera (Fig. 4 a). In individual assays the specificity determined from these sera ranged from $30 \%$ to $100 \%$ (Table 1, Fig. 4 b). Twentyseven assays $(67.5 \%)$ reported all the random blood donor sera as negative; a further five reported ICA in only one of the ten sera, but some assays had substantial problems with specificity (eg AE, O). The majority of assays with low specificity had poor precision (high precision scores). This is also shown after titres were interpolated into JDF units and using $5 \mathrm{JDF}$ units as a cut-off (Table 1).

\section{Detection limit}

The lower detection limit for ICA varied greatly between laboratories (Table 1). Some assays detected ICA in all 30 standard sera dilutions with titres of $1 / 8$ to $1 / 1024$, while others detected ICA at a maximum titre of $1 / 8$, and only in

a

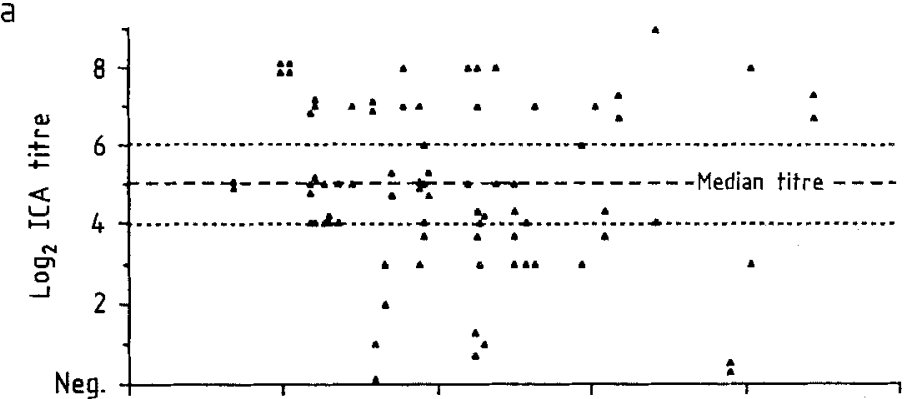

b

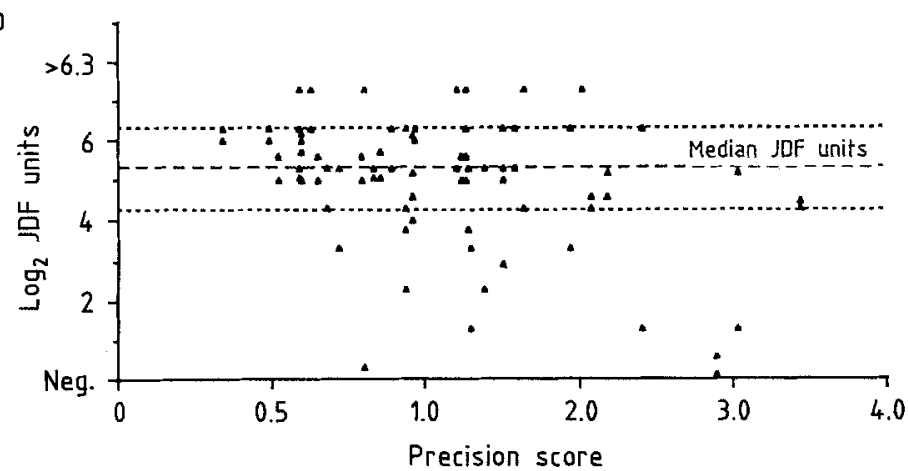

Fig. 3a,b. Comparision of ICA titres (a) and JDF units (b) obtained for the blind JDF standard serum. Results are plotted vs assay precision score, and the median titres or JDF units obtained by all assays are indicated. Dotted lines either side of the medians represent \pm 1 doubling dilution (titres) or $\pm 1 \log _{2}$ JDF units. Scatter of results improved after interpolation into JDF units $(72 \%$ of interpolated results within $1 \log _{2} \mathrm{JDF}$ units of median vs $43 \%$ of ICA titres within 1 doubling dilution of median titre; $p<0.005$ ). The scatter was significantly less amongst laboratories with small precision scores, particularly after interpolation into JDF units 


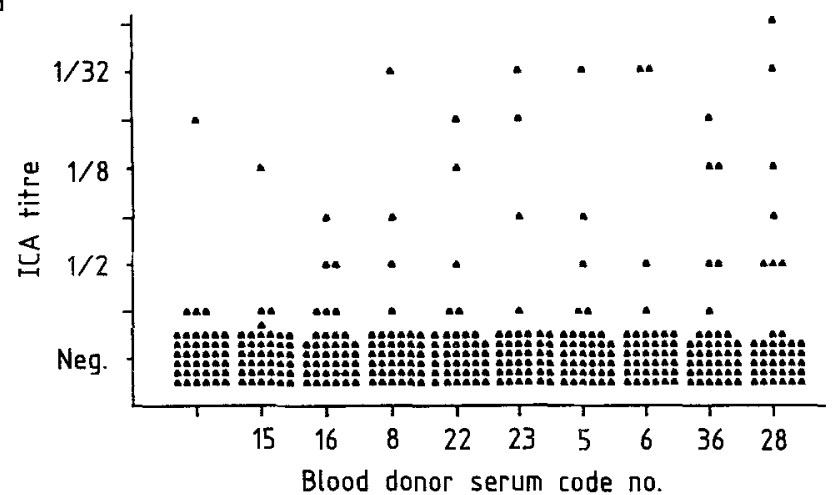

b

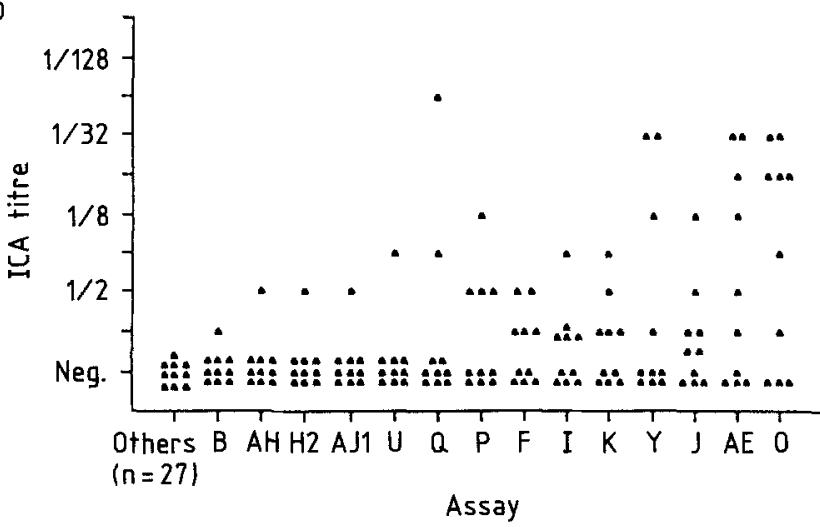

Fig.4a, b. ICA titres obtained for 10 random blood donor sera tested by 40 assays in the Workshop serum exchange. Low specificity was seen predominantly in a few assays with poor precision (see Table)

samples with the highest quantities of ICA. The mean titre for the 30 standard dilution samples reported in an assay ranged from $1 / 0.5$ (assays $\mathrm{R}$ and $\mathrm{AF} 1$ ) to $1 / 80$ (assay AA). The detection limit ranged from 50 down to $<5$ JDF units. Neither mean titres nor detection limits correlated with assay precision scores ( $r=0.18, r=0.10$, respectively).

Higher mean titres and lower detection limits were seen in assays incorporating extended incubation than in standard IFL assays when human substrate and FITC anti-IgG as second antibody were used $(p<0.025$, $p<0.05$, respectively; Wilcoxon rank sum test). In the eight assays using extended incubation, ICA was detected in the 30 standard dilutions in $211(88 \%)$ out of 240 tests, vs $451(76 \%)$ out of 594 tests from assays using the standard IFL technique $\left(\chi^{2}=14.3, p<0.0001\right)$.

\section{Discussion}

As seen in the Stage I and II Standardisation Workshops, there are large differences in ICA measurement between laboratories in Stage III. Although titres spanned up to 14 doubling dilutions, most laboratories detected ICA in samples with high levels of autoantibody, and the greatest discrepancies were seen in samples with lower titre ICA. The wide scatter of results was due to poor precision in some assays, and differences in detection limits between assays.
To assess precision within assays, their ability to: (1) reproduce results in multiple hidden duplicates, and (2) distinguish increments of ICA quantity defined by dilution were calculated. The resultant precision score was an arbitrary value giving a score of the ability of assays to do both. As expected, assays which could reproducibly quantify duplicates could also distinguish smaller increments than assays with poor reproducibility. The ability of assays to reproducibly quantify duplicates and discriminate levels of ICA varied considerably. Assays with high precision scores (poor precision) were incapable of reproducing and/or discriminating quantities of ICA. In addition, the data showed that results from such assays are less likely to be comparable to those from other ICA assays, even after interpolation into JDF units, and are more likely to detect ICA in non-diabetes related samples. Indeed, the large scatter of results for individual sera was largely contributed to by a few assays with poor precision.

Precision itself, was not dependent upon methodology. No method had better precision scores than others, and as only four assays used non-human tissues, it was not possible to assess whether precision was dependent upon tissue species. Interestingly, however, the one assay which used Bouin's fixed human pancreas had poor precision, and results were completely discrepant from the rest of the assays. Rather than methodology, precision was correlated with workshop participation. It is therefore expected that many laboratories with poor precision will improve with continued workshop and proficiency involvement. Improvement is also likely if standard sera are used routinely. For example, in the anti-nuclear antibody assay by IFL, precision improved when standard sera and standard curves were used routinely [23].

Another major cause of the large scatter of results was the large differences in detection limits between assays. As in previous workshops, the detection limit was influenced by methodology. However, even amongst precise assays of uniform methodology, differences in detection limits were pronounced and there were wide scatters of titres. Pancreatic sections have been shown to influence assay results [24], and therefore such differences may always remain. Given the variation of detection limits between assays, it becomes meaningless for laboratories to report results as positive or negative, or to compare data such as ICA frequencies obtained from different assays unless ICA are reported in common units. Reporting in the reference JDF units after interpolation of titres from the standard dilution curves did reduce the scatter of results, and improve comparability. Importantly, this reduction was greatest amongst assays with the best precision. It is essential that for standardisation to occur, laboratories improve the precision of their assays in addition to quantifying ICA. A "proficiency programme" is in operation to help laboratories assess their precision and to calibrate standards. Any new assays which are developed are also encouraged to participate in the programme.

Finally, it must be remembered that the IFL assay for ICA is likely to measure polyclonal antibody to a variety of islet antigens. Such a test may always have inherent variability between assays simply because of variable expression of antigens between tissues and different anti- 
bodies between sera. Precise quantitative and comparable ICA assays have been identified, allowing such differences to be properly assessed. The IFL test for ICA is still the most useful screen for identifying people at risk for Type 1 diabetes, and, until such time as the relevant antigens are identified and purified in large quantities, it remains the method of choice for its detection.

Acknowledgements. This manuscript is a detailed analysis of the Stage III ICA Standardisation Workshop data. We are grateful to the Juvenile Diabetes Foundation - International (USA) for sponsoring the Stage III Workshop held in New York, 25-26 October, 1987, and the Stage IV Workshop held in Auckland, 30 November, 1988 , and for their continued support of the standardisation programmes. We thank Ms H. Richter-Oleson for her excellent work in sample preparation, and all participants. For further Details on the "proficiency programme", please conłact Dr. N. Maclaren, Department of Pathology and Pediatrics, University of Florida, College of Medicine, Box J-276, Gainsville, FL 32610, USA.

\section{References}

1. Tarn AC, Thomas JM, Dean BM, Ingram D, Schwarz G, Bottazzo GF, Gale EAM (1988) Predicting insulin-dependent diabetes. Lancet I: 845-850

2. Srikanta S, Ganda OP, Rabizadeh A, Soeldner SJ, Eisenbarth GS (1985) First-degree relatives of patients with type 1 diabetes mellitus: islet-cell antibodies and abnormal insulin secretion. N Engl J Med 313: 461-464

3. Bruining GJ, Molenaar JL, Grobbe DE, Hofman A, Scheffer GJ, Bruining HA, De Bruyn AM, Valkenburg HA (1989) Ten-year follow-up study of islet cell antibodies and childhood diabetes mellitus. Lancet I: 1100-1103

4. Groop LC, Bottazzo GF, Doniach D (1986) Islet cell antibodies identify latent type 1 diabetes in patients aged 35-75 years at diagnosis. Diabetes 35:237-241

5. Irvine WJ, Sawers JSA, Feck CM, Prescott RJ, Duncan LJP (1979) The value of islet cell antibody in predicting secondary failure of oral hypoglycaemic agent therapy in diabetes mellitus. J Clin Lab Immunol 2: 23-26

6. Gleichmann H, Zorcher B, Grenlich B, Gries FA, Henrichs HR, Bertrams J, Kolb H (1984) Correlation of islet cell antibodies and HLA-DR phenotypes with diabetes mellitus in adults. Diabetologia 27: 90-92

7. Marner B, Agner T, Binder C, Lernmark $\AA$, Nerup J, MandrupPousen $T$, Walldorff $S$ (1985) Increased reduction in fasting $C$ peptide is associated with islet cell antibodies in Type 1 (insulindependent) diabetic patients. Diabetologia 28: 875 880

8. Wallenstein $M$, Dahlquist $G$, Persson B, Landin-Olsson $M$, Lernmark $\AA$, Sundkvist G, Thalme B (1988) Factors influencing the magnitude, duration, and rate of fall of $\mathrm{B}$ cell function in Type 1 (insulin-dependent) diabetic children followed for two years from their clinical diagnosis. Diabetologia 31: 664-669

9. Mandrup-Poulsen T, Nerup J, Stiller CR, Marner B, Bille G, Heinrichs D, Martell R, Dupre J, Keown PA, Jenner MR, Rodger NW, Wolfe B, Graffenried BC, Binder C (1985) Disappearance and reappearance of islet cell cytoplasmic antibodies in cyclosporin-treated insulin-dependent diabetics. Lancet 1:599-506

10. Boitard C, Feutren G, Castano L, Debray-Sachs M, Aisan R, Hors J, Bach JF (1987) Effect of cyclosporin A treatment on the production of antibody in insulin-dependent (type 1) diabetic patients. J Clin Invest 80: 1607-1612

11. Bottazzo GF, Florin-Christensen A, Doniach D (1974) Islet cell antibodies in diabetes mellitus with autoimmune polyendocrine deficiencies. Lancet 2: 1279-1283

12. Pilcher C, Elliot RB (1984) Improved sensitivity of islet cell cytoplasmic antibody assay in diabetics (Letter). Lancet 1:1352

13. Madsen OD, Landin Olsson M, Bille G, Sundkvist G, Lernmark $\AA$, Dahlquist G, Ludvigsson J (1986) A two-colour immunofluorescence test with a monoclonal human proinsulin antibody improves the assay for islet cell antibodies. Diabetologia 29: 115-118

14. Srikanta S, Rabizadeh A, Omar MAK, Eisenbarth GS (1985) Assay for islet cell antibodies: protein A-monocloncal antibody method. Diabetes 34: 300-305

15. Kobayashi T, Sugimoto T, Itoh T, Kosaka K, Suwa S, Sato K, Tsuji K (1986) The prevalence of islet cell antibodies in Japanese insulin-dependent and non-insulin dependent diabetic patients studied by indirect immunofluorescence and by a new method. Diabetes 35: $335-340$

16. Krell J, Rabin BS (1984) Comparison of an immunohistochemical and immunofluorescence procedure to detect antibody to pancreatic islet cells. Diabetes 33: 709-711

17. Bottazzo GF, Dean BM, Gorsuch AN, Cudworth AG, Doniach D (1980) Complement-fixing islet-cell antibodies in type-1 diabetes: possible monitors of active beta-cell damage. Lancet 1 : 668-672

18. Dib SA, Colman PG, Dotta F, Tautkus M, Rabizadeh A, Eisenbarth GS (1987) Expression of cytoplasmic islet cell antigens by rat pancreas. Diabetes 36: 982-985

19. Bottazzo GF, Gleichmann H (1986) Immunology and Diabetes Workshops: Report of the First International Workshop on the Standardisation of Cytoplasmic Islet Cell Antibodies. Diabetologia 29: $125-126$

20. Bonifacio E, Lernmark $\AA$, Dawkins RL (1988) Serum exchange and the use of dilutions have improved precision of measurement of islet cell antibodies. J Immunol Methods 106: 83-85

21. Gleichmann H, Bottazzo GF (1987) Islet cell and insulin autoantibodies in diabetes. Immunol Today 8: 167-168

22. Boitard C, Bonifacio E, Bottazzo GF, Gleichmann H, Molenaar J (1988) Immunology and Diabetes Workshop: Report on the Third International (Stage 3) Workshop on the Standardisation of Cytoplasmic Islet Cell Antibodies. Diabetologia 31: $451-452$

23. Bonifacio E, Hollingsworth PN, Dawkins RL (1986) Antinuclear antibody: precise and accurate quantitation without serial dilution. J Immunol Methods 91: 249-255

24. Marner B, Lernmark $\AA$, Nerup J, Molenaar JL, Tuk CW, Bruining GJ (1986) Analysis of islet cell antibodies on frozen sections of human pancreas. Diabetologia 25: 93-96

Received: 14 March 1990

and in revised form: 9 July 1990

Dr. G.F.Bottazzo

Department of Immunology

University College and Middlesex School of Medicine

40-50 Tottenham Street

London W1P 9PG

UK 